\title{
7. Precedence, Contestation, and the Deployment of Sacred Authority in a Florenese Village
}

\section{David Butterworth}

\section{Introduction}

'There will be no road through the middle of our village!'

Thus declared the 'source of the domain' (tana pu'an) of Romanduru village in the central highlands of Sikka Regency in April 2006, and to this day the proposed road has not been built. In this paper I elucidate the legitimacy of the authority of the tana pu'an in this matter by identifying the order of precedence that differentiates the status of the clans of Romanduru. In doing so I describe various strategies used to contest this order of precedence and argue that the contestation in fact strengthened the authority of the tana pu'an..

Since Lewis (1988:81) first translated the Tana 'Ai term oda as 'precedence', the concept has been central to our understanding of the Sikkanese speaking peoples. Lewis (1996a, 1996b) has subsequently provided us with studies of precedence in two of the three Sikkanese speaking societies, namely the people of Sikka and of Tana 'Ai. The significance of the third community, who are conventionally named the people of Krowé ${ }^{2}$ and of which Romanduru village is a part, is hinted at by their central position in the geographical and cultural continuum that stretches from the lowland Sikka in the west of the Regency, through the highland Ata Krowé in the centre, to the Ata Tana 'Ai in the far east (see Map 1). Lewis (this volume) notes that while precedence maintains its primacy in Tana 'Ai social organization, among the Ata Sikka precedence was augmented, and in some cases displaced, by an hierarchical form of social stratification as this society became a rajadom. I have argued elsewhere (Butterworth 2008) that contemporary Krowé society exhibits a social organization and cosmology that is in many ways similar to what we know of the non-rajadom and non-Catholic aspects of Ata Sikka society, ${ }^{3}$ and correspondingly is notably different from the Ata Tana 'Ai. In this socio-historical context the significance of the Krowé for comparative studies of precedence becomes immediately apparent. The Krowé have lived a different history to the Ata Sikka; a history that has kept them at the margins of the hierarchical rajadom and has only admitted Catholicism to any significant degree in the last 70 years. Importantly, the people of Krowé have conserved the social consequence of precedence to a much greater extent than the Ata Sikka. 


\section{Map 1. Map of Sikka Regency}

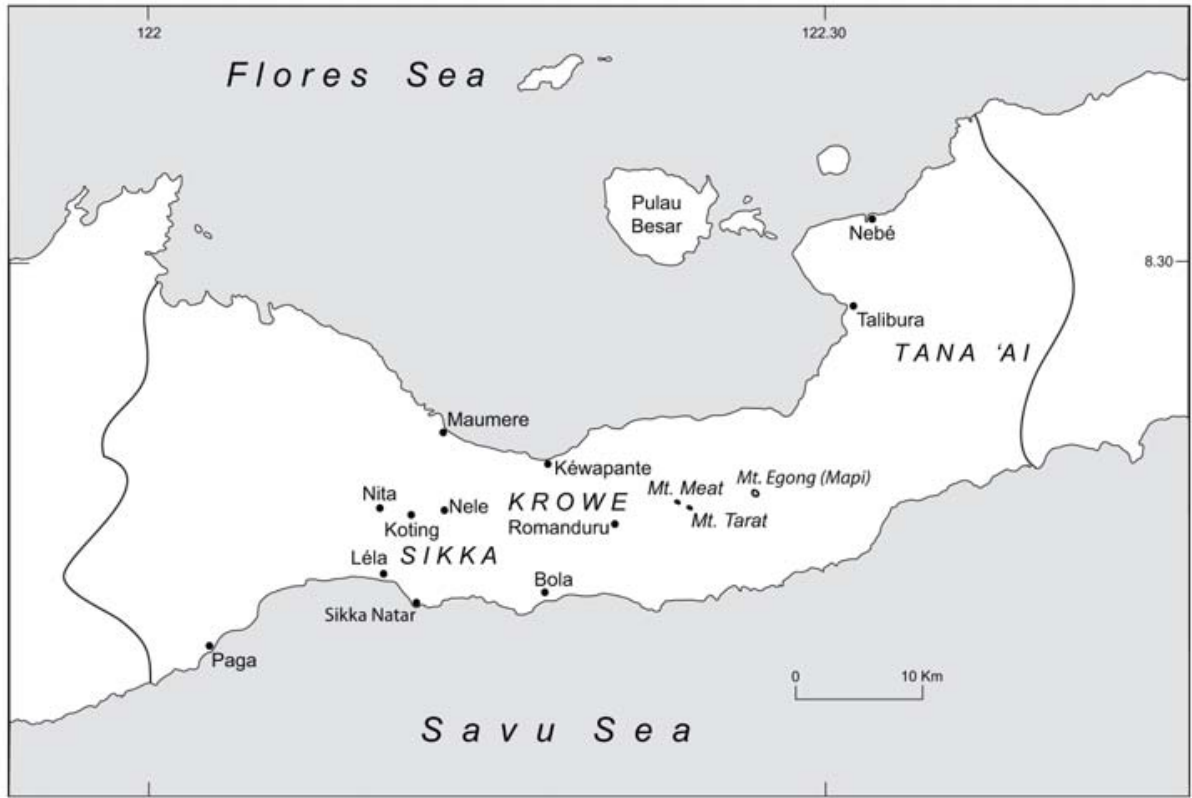

The relevance of precedence as a principle of social organization in Romanduru, and in the neighbouring Krowé villages, is evidenced by the continuing importance of the position of tana pu'an (source of the domain). In simple terms, the tana pu'an is a position of special social and spiritual responsibility that is accorded to the clan (and is personified by the clan headperson) which first settled in a particular domain (tana). The tana pu'an is the linchpin of Krowé orders of precedence that join clans within and between particular domains, and its persistence is noteworthy on two counts. First, some 25 years ago in a study of agriculture and population pressure in Sikka Regency, Joachim Metzner (1982:86) asserted that '... the institution of the tana pu'ang and the council of elders dealing with land issues ( $d u^{\prime} a$ mo'ang watu pitu) have ... disappeared in most of Central Sikka' ${ }^{4}$ My research indicates that, at least in Romanduru and the surrounding villages, the tana pu'an institution has not disappeared and, moreover, 'land councils' of elders still function, albeit in an informal capacity when compared to the formal authority of secular government apparatus. This brings us to the second point of significance of the tana pu'an. Although the authority of the tana pu'an is derived from and sanctified by the indigenous religious cosmology, this authority is nonetheless meaningful in ostensibly secular contexts. That is, on certain occasions, especially with regards to issues of land use, land tenure and natural resource exploitation, the sacred authority of the tana pu'an can effect secular change (or, as it may be, prevent change). For the Krowé, whose lifeworld articulates a complex mixture of 
indigenous, Catholic and Muslim influences, the sacred is rarely divorced from seemingly secular events, and precedence is a form of social organization that unites these sacred and secular spheres.

The case study I present to illuminate Romanduru's order of precedence and the authority of the tana pu'an is an event that outwardly reflects an antagonism between tradition and modernity. In short, some inhabitants of Romanduru advocated that a new road be constructed through the centre of the village to improve transport for those living some distance from the sole access road located at the top of the village (see Figure 1). Other inhabitants disapproved of the proposal because the road would require the destruction of much of the natural rock formations (which hold religious significance) and the relocation of some of the ritual altars that constitute Romanduru's centre. While this is a small-scale and highly localized dispute, its substance is representative of a wider tension between the value of sacred sites and the imperatives of economic development. However, as I untangle the motivations behind the Romanduru road project and the factors that have led to its denial, I will emphasize that a rubric of 'tradition versus modernity' does not entirely explain this controversial event. That is, what we find in the rejection of the Romanduru roadworks is not simply a triumph of traditional values over a modern infrastructure development, but an intricate social play of authority and contestation that is an expression of inter-personal and inter-clan relationships of precedence.

Precedence is a part of Romanduru tradition because it is produced in the complex of cosmology and sociality that is known by the villagers to have been the indigenous practice of their ancestors. At the same time, precedence is a part of contemporary thought and practice and it warrants recognition as a fundamental part of Romanduru inhabitants' current lifeworld (including their ways of creating and resolving disputes). In this way, precedence is a type of social organization that connects tradition and modernity in the Krowé communities, and cannot be considered simply as a throwback to an earlier mode of living. With this debate in mind, the objectives of this paper are twofold. First, I will describe the order of precedence of the Romanduru clans and explain the authority of the tana pu'an based on this order. Second, I will show that the proposal and rejection of the Romanduru roadworks can only be fully understood when precedence is posited as a theory of contemporary social action. 
Figure 1. The village of Romanduru taken from the grounds of Santa Maria Senior Secondary School. Note the rock formations and ritual altars in the village centre which would be affected by the proposed road

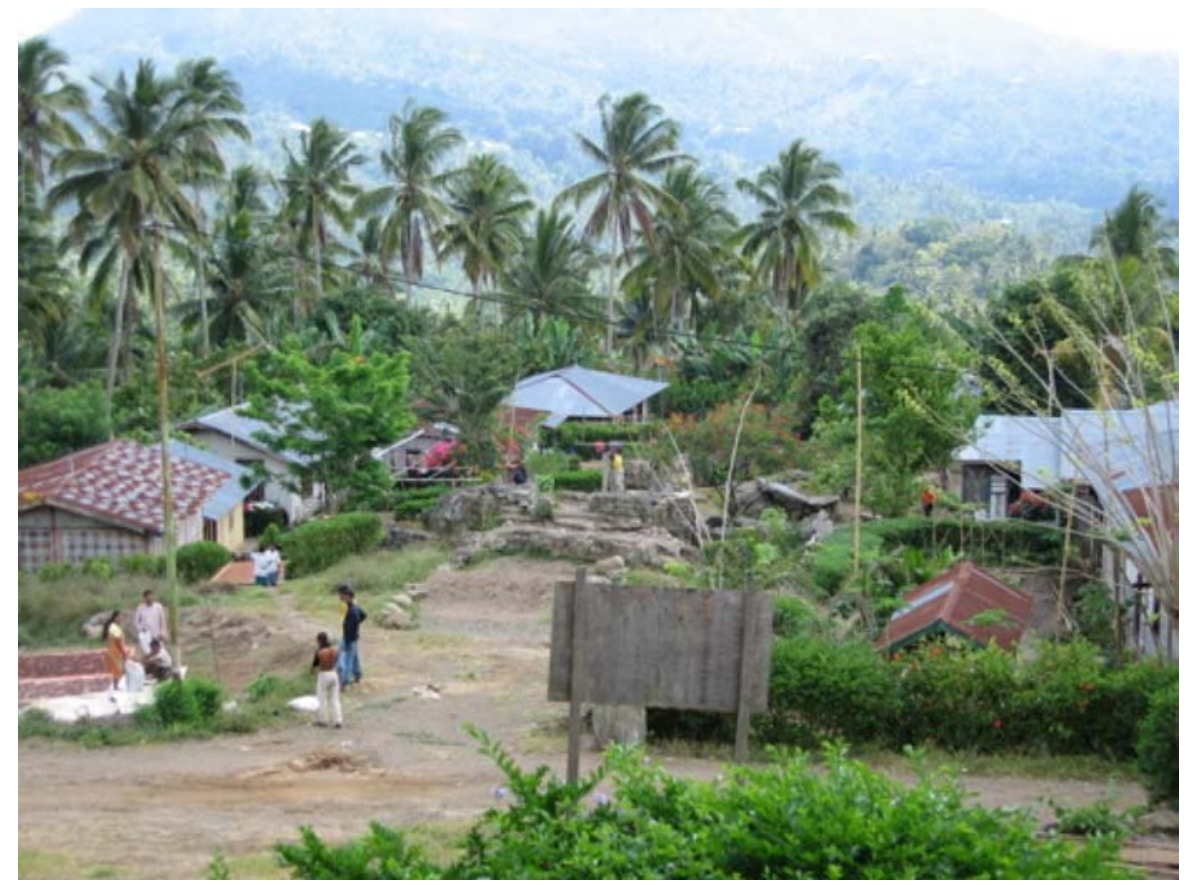

\section{The Social and Cosmological Bases of Precedence in Romanduru}

According to the Krowé logic of precedence, the relative proximity of a domain's clans to the indigenous godhead is indexed to the clans' sequenced arrival and settlement in the domain. The earlier a clan settles in a domain, the closer it is to the deity, and the more responsible it is to the deity for the well-being of the domain. There are several social and cosmological aspects of Krowé life that must be explained in order to understand this operation of precedence. We must first define 'domain' and 'clan' and discern the relationship between the two. We must then explain how the connection between clan and domain is configured as a connection between the founding clan and the deity.

The village of Romanduru stands on the western slopes of Mt Méat in the central mountains of Sikka Regency in the eastern Indonesian Province of Nusa Tenggara Timur (NTT). In 2006 the population of Sikka was 282,795, of whom at least three quarters speak the dialects of the Sikkanese language. ${ }^{5}$ At this time Romanduru consisted of 53 households which were home to 224 people, and the surrounding villages have similar numbers. In this densely populated area Romanduru and its neighbouring villages dot the sharp ridges and saddles 
that extend down from the mountain peaks. ${ }^{6}$ The first point essential to our understanding of Krowé precedence is that in this region the traditional 'origin villages' (natar gun) and clans (suku or kuat wungun) are inseparable because such villages are constituted by clan wards ('wisung wangar). ${ }^{7}$ Wards are small adjoining parcels of land on which clans have their central houses ('wisung wangar lepo woga). In villages constituted by such wards' houses are built within metres of each other, water is gathered from the same spring, and men, women and children of different clans share their daily lives. The clan ritual altars ( $w u^{\prime} a$ mahé) also stand side-by-side in the middle of the village, and on special occasions (such as the lodo hu'er mortuary ritual) all are jointly offered sacrifices. These wards and altars are the nexus of village and clan identification. That is, through these sacred plots of land and assemblies of stones different clans join as one village.

All origin villages are located in their own domain called a tana, and each has a source, or founder, called the tana pu'an (source of the domain). In fact, the village and domain are essentially the same entity, and are unified in local idiom as natar tana (village domain). Domains in Krowé are demarcated by borders (duen geté hoat mosang) signposted by certain physical landmarks such as trees and valleys, in ritual activity located at the borders, and in the memories of community members. The tana pu'an is the clan that was the first to settle in the area, establish a 'wisung wangar ward and erect a wu'a mahé altar. There are in fact two types of tana pu'an in Krowé domains; the tana pu'an hoak héwér (the source of the domain who has pinned his headdress to the tree) is the foremost source of the domain, and he may delegate authority over segments of his land to the tana pu'an luli hodan (the source of the domain poured out from the bowl). However, in the relatively small domain of Romanduru only the former type of tana pu'an was operational at the time of my fieldwork. The villages are formed around the source clan by the subsequent inclusion of other clans who also establish a 'wisung wangar clan ward and erect a wu'a mahé ritual altar.

In ritual language the members of the same clan are called ue lu'ur liwun, wari lodar lélén. This nomenclature is significant and worth noting. Ue (or wue) refers to 'elder sibling' and wari 'younger sibling'. The terms lu'ur and lodar are synonyms that can be glossed as 'successive', 'lined up in a row', or 'straight', while liwun and lélén mean 'together' or 'in union'. The phrase 'elder and younger siblings lined up together' gives only some indication of the complex meaning contained in the original couplet. For example, and as will become more apparent below, the meaning of ue and wari extend beyond strict sibling relationships and encompass broader social relationships. Furthermore, the close lu'ur relationship, denoting people of the same clan, can be contrasted with dolor relationships which denotes people who are related but of different clans (see Lewis 1988:191 for the Tana 'Ai form of lu'ur dolor relationships). Within a clan, which are large corporations, social and ritual life revolves around the smaller 
nuclear family units, known locally as an orin or lepo woga (both of which mean house). This arrangement is typical of the 'house' communities found in eastern Indonesia, in which houses double as physical edifices and units of kinship, linked via the cosmological principles embedded in the house's construction and pattern of social relations (see Cunningham 1964; Fox 1993). A house essentially consists of an ina (mother), ama (father), and mé (children) who are nara (brother) and winé (sister). Social houses are created through marriage, dissolved when the couple dies, and remain unnamed except insofar as the names of the family members are used. The house of a clan's head-person, however, is always called the lepo geté (great house). In distinction to the broader clan, people of the same house often refer to themselves as ue wari lepo woga (elder and younger siblings of the house).

The number of clans residing in Krowé villages varies. ${ }^{8}$ The village of Romanduru, for instance, has the highest density of clans of the villages in which I worked, they being clans Buang Baling (tana pu'an), Mana, Klukut Mude La'u, Wodon, Lio Lepo Gai, Lio Watu Bao, Keitimu Lamen, Keitimu Wain, Wewe Niur, and Ili Newa. I have counted 35 clans in the region, however most people were not concerned with establishing an accurate count. In ritual language the phrase kuat wungung ${ }^{9}$ is used to designate a clan, whereas in everyday language it is called a suku. The phrase ata kuat is also frequently used, meaning "people of the clan'; thus ata kuat buang baling refers to the 'people of the clan buang baling'.

Clans, moreover, extend their field of influence outside the clan wards of villages because clan 'houses' (lepo woga) are also located in other villages, either having established 'wisung wangar in other villages in the distant past or settled in the new villages that have sprung up as the population has increased. Alliances are thus established by relationships between clans within a natar tana (village and domain) and, by extension, between villages which share the same member clans. In other words, alliances between villages are crystallized by the alliances of multi-local clans within villages. However, it is important to note that the structure of precedence of clans only operates within domains, not between domains. Thus, a clan which is the tana pu'an of one domain can be subject to the authority of another tana pu'an clan in a neighbouring domain. Whereas the social stratification evident within domains and villages is based on the different origins of clans, the relationship between domains and villages is a function of the multi-locality of clans. In other words, precedence relationships within villages bind clans together, and the multi-locality of clans bind villages together.

Having defined Krowé clans and domains and outlined their relationship in sociological terms, I will now examine the sanctity of this relationship that underwrites the spiritual authority of the tana pu'an. To do this I will look at three other elements of Krowé society in which precedence is expressed, namely; 
marriage, ritual and cosmogony. Precedence in Krowé society is largely premised on mythic origins that are at once human, spiritual and geographical. The minimal requirements for this system are the community's knowledge of the sacred connection between the deity and the domain, and their knowledge of sequence of the arrival of clans in the domain. However, in the local exegeses of origins there is a disjuncture in the narratives that treat the creation of the universe by the deity and the arrival of clans in the various villages and domains. Both events have a distinct corpus of mythology which do not make mention of each other, and each mythic history at first seems to represent a discrete conceptual domain. And yet, both events are related, as indeed they are related to the institution of marriage. In different aspects of Krowé social and spiritual life (such as marriage, ritual and cosmogony) precedence is structured by asymmetric dyadic sets that only find their full value through their systematic connection within a totality. Thus, while the precedence of the clans of a domain is structured by the political value attributed to the dyad 'first//subsequent', and is ostensibly free of spiritual value, the full value of this precedence order is only articulated in the community, and known to the ethnographer, when it is brought into relation with other orders of precedence.

When two clans contract a marriage they enter into an exchange relationship in which the wife-giving clan is known as ina ama (mother and father) and the wife-taking clan is known as me $p u$ (children and nephews/nieces). This itself constitutes a discrete order of precedence that is configured for the length of the exchange cycle of bridewealth and counter-prestations (usually the lifetime of the couple and sometimes beyond) in which the 'mother and father' clan is differentiated from, and cast as prior to, 'children and nephews/nieces'. In this case, precedence is accorded to the genitor, or life-giver, in favour to the progeny, or life-taker, on the basis of an order that indexes the bride and her clan as the source of life and the bridegroom and his clan as the offspring (see Fox 1996 for a discussion of the categorical validity of genitor and progeny instead wife-giver and wife-taker).

Although the 'marriage' order of precedence operates differently to the 'domain' order of precedence I focus on in this paper, its structure is useful in helping us appreciate the multiplicity of asymmetric values that simultaneously constitute Krowé orders of precedence. Since the precedence of the clans in a Krowé domain is determined by the sequenced arrival of those clans, the dyadic set of 'first//subsequent' represents the status differentiation of clans that was set in motion in the ancestral past and is reproduced in contemporary inter-clan relationships within a particular domain. With marriage, the dyadic set of 'genitor//progeny' represents the differentiation of wife-giver and wife-taker clans that is articulated when a women leaves her natal clan, enters her husband's clan, and gives birth to children for her new clan. The historical movement from first to subsequent is at once analogous to the movement of the wife between 
clans and the parting of mother and child during birth. The equivalence of these two dyadic sets, and the orders of precedence they represent, becomes even more evident when we delve deeper into the Krowé indigenous cosmology.

The Krowé cosmogonic myths and ancestral journeys of clans are narrated in a formulaic register of 'ritual language' that is composed in semantically parallel couplets. Ritual language, and the ideas it communicates, is part of a religious and ritual system which is called adat by the local community. Adat is an Indonesian word of Arabic origin used throughout the archipelago in reference to traditional and customary cosmologies and practices. However, the communities of Sikka Regency also use the term to refer specifically to their indigenous cosmology. In a community with no general native ethnonym, and, furthermore, no single native term for liturgy or ritual speech, it is not surprising that a foreign word stands instead of a native umbrella term for the indigenous religion. Here it is important to note that Krowé adat exists alongside Catholicism and the majority of the community practise both religions. For example, marriages are commonly conducted first according to adat and subsequently according to Catholicism. In the formidably syncretistic lives of the Krowé, Catholicism and adat are not contradictory, rather, they are regarded as complementary truths that have different genealogies and emphases.

The Krowé adat cosmogonic myths that I have collected and analysed depict the segmentation of an original, primordial unity and describe a relationship of obligation between humans and spiritual beings that provides the rationale for sacrificial ritual (see Traube 1986:13; Lewis 1988:45; McKinnon 1991:16 and Forth 1998:217 for similar cosmogonic themes in other eastern Indonesian societies). These sacrificial rituals, which are the most visible aspect of Krowé adat, are carried out at household altars (ulu higun) as piong tewok rites and at clan altars ('ai tali and wu'a mahé) as tung piong rites. All Krowé ritual activity, from the simplest to the most elaborate ceremonies, are based on sacrifice and involve offerings to the deity and ancestor spirits of rice, egg, tobacco, betel pepper and areca nut, fish tail and, depending on the event, offerings of raw and cooked chicken, dog and pig. Large public rituals, which are held on occasions of marriages, funerals, the implementation protection charms, and the building of new houses, roads, and public buildings, also involve complex arrays of other formulaic activities, such as material exchanges. Other occasions for ritual include return from or commencement of travel, study or work, times of illness and recovery, and requests for good fortune in any number of endeavours.

According to the Krowé cosmogonic myths, the primeval unity of all things is broken by the separation of the earth from the sky, the deity from humans, humans from animals, males from females, and good from bad. The consequence of separation and individuality is a mutual obligation between the human and spiritual realms in which the deity (called ina nian tana wawa, ama lero wulan 
reta [mother of the earth and land below, father of the sun and moon above]) provides the materials necessary for human life, and in return humans provide the deity with sacrificial offerings. The rituals of sacrifice fulfill obligations because they 'reconstruct the source' (wake pu'an) and reunite the primevally separated entities. During the 'heat' of ritual, humans, ancestors (nitu noan), the deity, and even the sacrificed animals, are joined together in a potent field of communication not otherwise experienced in normal life. Seen in this way, adat rituals not only benefit the human participants (for whom the ritual settles cosmological debts, sanctions social transformations such as marriage, and generally ensures good harvests, health and fortune) but also benefit the deity and ancestors. Like children returning home to their parents, reconstructing the source in ritual momentarily gives back to the deity and ancestor spirits their progeny, who become increasingly distant as over time they irrevocably move away from their source.

Krowé ritual practice and cosmogonic myths tell us that the deity is synonymous with the source of all things. In ritual, participants make supplications to the deity for the purpose of reconstructing the source and joining together all the beings and objects involved in ritual. Unhindered by temporal, geographical or cosmological distance, humans make the requests and the spiritual realm provide the assistance that allow life to continue smoothly. In effect, the cosmogonic myths speak of the segmentation of an original unity (which was constituted by the deity in its purest form) into the diversity of the world as we know it, and this segmentation is reversed by ritual as the original unity of the deity is momentarily re-formed. Thus, the dyadic sets that represent the precedence of clans with regard to marriage and domain relationships can be construed in terms of another dyadic set that represents the dynamics of ritual and cosmogony. I identify this as a structure of source//product, and in local idiom is represented variously as ai pu'an//tali ubut (tree trunk//vine tip), pu'an//tawa (source//growth) and wu'un//matan (bamboo node//bamboo sprout). The primeval source that is reproduced in ritual and defined as the deity is both the temporal first and the reproductive genitor. All things were created from the primeval source, and so too do the 'subsequent' clans follow the tana pu'an clan and the progeny of children and nephews (me pu) issue from their mothers and fathers (ina ama).

Precedence in Krowé operates in several, inter-related spheres. Cosmogony, ritual, marriage and domain clan relationships all exhibit a structure of precedence. By identifying the source//product structure in cosmogony and ritual it is not my intention to suggest that marriage and domain clan relationships are thus determined. Instead, I wish to illustrate that although particular dyadic representations of precedence are privileged (or, at least, more noticeable to the ethnographer) in the symbolism and practice of each sphere, all are nonetheless connected in a unitary system. The connection is semantic, such that the 
privileged idioms of, for instance, first//subsequent, genitor//progeny, source//product are all imagined as a movement from an origin point outwards through time and space. The connection is also maintained in the practical relationships between the different spheres of precedence as they are enacted. For example, marriages are rituals that make contracts between clans, clans live in domains and the existence of both is explained in mythic histories, and cosmogonic histories contain themes that are enacted in marriage ritual. Thus, in local imaginations fed by, and which feed into, the symbolic and practical activities of marriage, ritual, myth, clan and domain, the 'first' is semantically and practically linked with the concepts of 'genitor' and 'source', and 'subsequent' is equated with 'progeny' and 'product'.

In sum, in Krowé the first clan that settles on a domain becomes the source of that domain with reference to the subsequently arriving clans. The physical land and biological life that constitutes the domain itself has a source in the form of the deity. The human and spiritual sources of the domain are thus linked in a special relationship. This is not to say the tana pu'an clan is the deity, rather that this founder clan is closest to the deity in another order of precedence that proceeds from source of the universe (deity), to source of the domain (tana pu'an), to delegated tana pu'an luli hodan positions, to other clans of the domain, and, if we extend the sequence, to individuals not affiliated to a clan of the domain. With the position of tana pu'an comes the responsibility for the well-being of the land and success of harvests in the domain because, being closer to the deity, the tana pu'an is able to make more effective entreaties to the deity. In return for this responsibility the source clan receives tribute called wawi peping ara piong (the pig's jaw and rice offering) from the other clans. The tana pu'an is primarily a spiritual position based on a close relationship, via the particular tana (domain), with the deity.

\section{The Order of Precedence of Romanduru Clans}

One of the tenants of the theory of precedence is that there can be several co-operating values in any one order of precedence. In the previous section I argued that the order of precedence among the clans living in a Krowé domain is fully articulated when the privileged dyadic set of first//subsequent is augmented by the values of other, related orders of precedence. Thus, the temporal first also contains the values of source and genitor. In this way the founding clan of a domain, as source and genitor, is brought into a relationship with the deity, and thereby assumes certain responsibilities over the domain and the people within it. In this section I will focus on the specific order of precedence among clans in Romanduru as it is expressed in the mythic history of the tana pu'an clan of Romanduru, Buang Baling. Through this analysis I will introduce another dyadic set that further valorizes of the order of clan precedence within domains. The mythic history represents the distinction between first 
clan and subsequent clans in terms of a distinction between elder and younger. The asymmetric relationship between the clans of a domain are therefore valorized in a way that in part duplicates the relationships of elder and younger siblings which, as I emphasized earlier, constitute individual clans.

The Buang Baling clan history presented below sourced from the notebooks of Mo'ang Elias Esi, a native of Koting. As a young man in the late 1960s Esi travelled throughout the Krowé region recording clan histories and other adat knowledge. This particular narrative was recorded from a Buang Baling chanter named Mo'an Raga Dobo Piring from the village of Dobo. During my fieldwork I did not witness clan histories recounted with the depth and breadth of description, or the remarkable poetics, of this narrative (which in its totality contains 698 lines of strictly parallel verse). Nonetheless, the fundamentals of clan histories are still widely known and spoken by members of Romanduru clans.

Clan histories are part of a genre of ritual speech called kleteng latar (bridging speech). Literally, kleteng refers to a bridge made of wood and vine ropes spanning a creek or river. This metaphor evokes the primary function of ritual language as a method for enabling clear and effective communication, be it between the human and spirit realms, or simply between humans. More specifically, kleteng latar defines ritual language that explicates ethics, law or history. In the later case, it is used interchangeably with ngeng ngerang (dispersal of generations) and is commonly used in an argumentative and entertaining manner in which two people recite their clan histories in tandem while testing each others knowledge. Histories are also often chanted immediately before or upon death to ease the transition of the deceased's soul (maen) to the afterlife (nitu natar noan klo'ang). It is said that reciting the names and travels of the deceased's clans' early ancestors, provides necessary guidance for the soul as it seeks to join its fellows.

I will present a selection of the Buang Baling narrative that explicitly deals with the question of precedence. Before proceeding, it is important to note that Krowé clan histories are examples of what Fox (1997) has called a 'topogeny'. In reference to the Atoin Meto of Timor, McWilliam explains that a topogeny is an

ideology of affiliation through fathers to sons [which] tends not to be expressed genealogically in the record of particular generations of named ancestors, but rather spatially across the landscape by associating the group's name with specific places and named localities (1997:103).

For the Krowé, membership to clans is immediately reckoned through patrilineal descent, however the historical corporate stability of clans is not reckoned by unbroken genealogies stretching back into the distant past. Clans are defined 
both contemporarily by the lives of one's grandfathers, grandsons and those in between, and historically by the journeys of one's earliest ancestors. Moreover, the journeys link clan ancestors to particular physical features and tracts of land. This link is of most consequence when clans end their journeys and found a village and domain.

The Buang Baling history begins with the departure of Du'a Wio Bota ${ }^{10}$ (female) and Mo'an Supung Balen Sina (male) from the island of Bali after a natural disaster which is described as 'kasi nian mutu o bitak, bitak nang ganu pigang, blua nang ganu kleto' (Oh my land was destroyed, it cracked like a fallen plate, like the worms turn the earth). Throughout the narrative the Buang Baling ancestors visit various locales and meet numerous travellers from other clans. I recount a selection that begins towards the end of the narrative, when Du'a Wio Bota have already journeyed along the south coast of Sikka Regency and upwards into the central mountains (like most Krowé clan histories, the male counterparts of the leading female ancestors disappear from the narrative quite early). The story begins at a place called Klo'ang Gunit, a temporary settlement of Du'a Wio Bota near the as yet undiscovered Romanduru. Du'a Wio Bota pause in search of water:

$a^{\prime} u$ Wio a'u Bota

580 teri puput ling kiok ora dota degang kletak

582 ulit eh ra'i wair boir sa mara wair

584 po ita wair nora pu'an a'u huk du uku aka

586 nera du pokang peler $a^{\prime} u$ huk poi e uwung

588 nera poi e nain ana tupat kokor

590 sisi ora awu luk pete e ahu i'ur

592 ahu Jawa ahu Mola ahu ia bano dete

594 awu ia luk lurus

\section{I am Wio I am Bota} sitting to fan the flames swinging my hammer and striking my skin is dirty and needing water my throat is dry and thirsty for water

we look for a water spring

I think and deliberate

I meditate and consider

I think deep in my heart

I consider with my life's breath

a basket made from plaited coconut leaves

filled with fine ash tied to the dog's tail the dogs named Jawa and Mola the dog leads the way the ash is fine

Du'a Wio Bota then follow the trail of the ash as the dogs run in search of water. The narrative takes the listener (or reader) on a tour of the streams and spring waters that surround the village of Romanduru: 
wae e ripa $b a^{\prime} u$

596 ripa wair puat rano dadin wair ia meting poi marat poi

598 ahu ia bano dete ripa lawang ba'it henan blanun

600 loret loret ripa ba'u ripa wair herit bere seng

602 ia du meting poi marak poi ledu leder lau ang

604 era ni'a era kliat

ahu ia poa wi'in poma wi'in

606 a'u ata higi mitan heading down to the right

to the spring waters forming a pond the water there has dried up the dogs lead the way to Lawang Ba'it Henan Blanun descending further down to the right to the spring of Herit Bere Seng there it is also dry in single file down they go standing looking, standing considering the dogs splash and play in the water I am a wise person with coloured teeth $^{11}$

The discovery of a rich waterhole confirms the wisdom of Du'a Wio Bota and, indeed, expresses the sympathetic relationship that they have for this locale. The Buang Baling ancestors excavate the spring so that the water 'flows free and pure', and then walk upslope to survey the site of the future settlement:

di ni'a lau a ita

608 teking ora kebung rebu

'o'i wawa wa'u ali

610 ali 'ata golo wair lema reta loki klasar

612 ahu gita beli wair wair wulut liro linok

614 ahu i'ur jewa jaong

wai dahi rawong

$616 a^{\prime} u$ Wio a'u Bota hu'i ripa wa'un ta'u

618 popo ripa wa'un te ban buno ripa napun blatan

620 ripa napun tepak blikon blawan now I look down, seeing carrying a branch of sugar palm ${ }^{12}$ wood

shovelling and digging downwards digging and discovering much water ascending to the rocky outcrop ${ }^{13}$ the dog sees and gives water at wair wulut liro linok ${ }^{14}$

the dogs' tails wag and splash the water

the water flows free and pure I am Wio I am Bota bathe and collect water there wash and dry there the cool water flows through the valley

at the stream sloping this way and that

Having found a spring around which to establish a village the two women are joined by Du'a Saru and Du'a Watu, ancestors of two other clans. Du'a Watu 
married Mo'an Blua to form clan Klukut Mudé La'u, and Du'a Saru married Mo'an Bela to form clan Mana. In the following instalment the structure of precedence is introduced. As the pair from clan Buang Baling meet the newcomers they invite (pahar) them to stay and build a village together (line 664, 665, 670). In this final section of ritual speech the narrator switches between speaking in the first person of both Du'a Wio Bota and Du'a Saru Watu. Thus:

$654 a^{\prime} u$ Saru a'u Watu $a^{\prime} u$ hu'i wali ang ta' $^{\prime}$

656 popo wali ang te a'u lair ra'intan golo ue

658 wuen ${ }^{15}$ Wio wuen bota wuen lau nian ngeng

$660 a^{\prime} u$ tangar regang golo wuen lau tana ngerang

662 wuen lau tana ngeng wuen Wio wuen Bota

664 'au pahar wi meti pita pahar Saru wai Watu

666 idet wi doé mala nane Laju du'a Plu'e

668 warin lau tana ngerang uen Wio wuen Bota

670 pahar wi meti pita libu wi'it liar liwun

672 kula wi'it ganu wulan ita ro'a le'u duru e

674 tena song sugo tion kara wi'it ganu lero

676 ita sapi le'u klukut oh tena kadang hereng belan

678 song na'in sugon tion sugon tion dadi lepo
I am Saru I am Watu

I bathe and collect water there

I wash and dry there

I know who my elder siblings are

Elder Wio elder Bota

they came down inhabiting the land I meet and respect them

elders who came down dispersing on the land

elders who came down giving descendents

elder Wio elder Bota

eagerly you invite us to stay

inviting the wives Saru and Watu

pulled in and held in hand

with Du'a Laju Plu'e

younger siblings dispersed on the land

elder Wio elder Bota

an invitation made eagerly

together our voices are one

conferring with each other like the moonlight

we clear the duru trees

making the correct measurements of our houses

deliberating with each other like the sunlight

we clean away the rubbish

oh we ensure the foundations are properly set

placing the correct measurements correct measurements become a house 
$680 a^{\prime} u$ Wio a'u Bota turu weli nora wisung

682 wisung wae lau ba'u lau likong tana klasar

684 lau saru lau watu a'u tutur weli 'au

686 nora wangar wangar wae wali main

688 hi'ung wali na glikung du'a pli'at ba'a ganu liat

690 leta wi'it let wi'it ta lako dueng geté

692 pani wi'it gaging wi'it bar tana hoat mosan

694 tana a'u ler mangan

dadi ami ruga ba'a ubut tobong

696 nian ami liting gi'it ami paket tadan ba'a olan lahin

698 dena tana ler mangan
I am Wio I am Bota

pointing out a dwelling place a dwelling place facing from down there $^{16}$

from down at Likong Tana Klasar from Saru and Watu

I speak and give you

a place to reside

a dwelling place facing the southern winds 17

others glance towards us jealously

our women have already built hearths

welcoming and encouraging each other

going to visit the great borders

of one mind and direction

calling upon the principal

boundaries

the land upon which I lean with strength

so we have trimmed the tips of the trees

the earth upon which we rest with surety

we have raised tadan $^{18}$ and marked our place

making this our land and strength

In lines 658, 661, 662, 663, 668 and 669 of this passage an 'elder//younger' (ue wari) relationship is explicitly formed between Buang Baling (as elder) and clans Klukut Mudé La'u and Mana (as younger). Thus, the terminology of ue wari, normally used for members of the same agnatic clan, is applied within the village for members of different clans. There is great clarity and forcefulness in the assertion of the brotherhood of the clans - they are, as is stated in line 692, 'of one mind and direction'. The position of the 'elder' tana pu'an is by no means autocratic, and by virtue of their co-residence on the same tana all the clans are united in a fraternal bond. Furthermore, it is important to remember that, as I stated earlier, this structure of precedence only operates within tana, not between tana, and a clan who is 'younger brother' to the tana pu'an of one territory can be its 'elder brother' in another. 
The Buang Baling clan history establishes a structure of precedence that is archetypal for all clans and domains in Krowé. A domain is first discovered and settled by a particular clan, and subsequent arrivals are incorporated into the settlement under the auspices of the first clan. This structure of precedence burdens the source clan (tana pu'an) with the honour and responsibility of mediating the relationship between the deity and the people who live upon the domain. Importantly, the precedence-based stratification of clans within Krowé domains operates with a simple division between the first arrival and 'the rest'. The different clan histories do give a general idea of their sequenced arrival. For example, in the history presented above we see that clan Buang Baling was immediately followed by clans Mana and Klukut Mudé La'u and none of the other seven clans had yet arrived. However, unlike in the neighbouring community of Tana 'Ai where the sequential order of clans is recapitulated and contested in the Gren Mahé rites (Lewis 1988), according to my data this extended order does not presently have social or ritual consequences in Krowé. For example, as I noted earlier, the tana pu'an is differentiated from other clans in ritual activity with the tribute wawi peping ara piong (the pig's jaw and rice offering). In the past, when subsistence agriculture was still practised, this tribute to the source of the domain would occur regularly with harvest, however, nowadays it mostly occurs when public village land is put to use. I have witnessed several instances of this tribute, all as components of rituals that consecrate construction (laba lepo sorong woga). The tribute on each occasion was a token amount of money given to the tana pu'an on behalf of all the other clans of the domain acting in unison.

\section{Strategies of Contestation and the Legitimization of Authority}

In this section I relate the strategies deployed by both the tana pu'an and the pro-road faction as they argued their respective positions. I wish to emphasize that both factions in this dispute could muster persuasive reasons for and against the road construction. Indeed, I suggest that the dispute was not primarily about the road, but was a calculated test of the Romanduru order of precedence for which the road was a means, or front, to enact this contestation.

The centre of Romanduru village, where the road in question was proposed to be built, is constituted by a natural rocky outcrop (loki klasar), ten ritual altars (wu'a mahé) — one for each of the village's clans - and the convergence of the ten clan wards ('wisung wangar), which are rectangular parcels of land located side-by-side in two parallel rows. These aspects of the village are sacred for the inhabitants of Romanduru, all of whom adhere to the indigenous cosmology. The rocky outcrop is known as a gateway to a potent, and dangerous, spiritual domain and is the home of a spiritually empowered python (naga sawaria). The ritual altars were erected by each clans' earliest ancestors and are 
used for the final stage mortuary rites called the lodo hu'er. The clan wards are the physical nexus at which humans join together as a community under the auspices of the deity. Thus, each aspect holds an extremely important place in the imaginations and practices of the community, and the destruction, removal or modification of these sacred sites and objects would represent a transgression against the deity.

The authority of the tana pu'an over the village and domain of Romanduru is underpinned by the order of precedence which connects the temporal priority of clan Buang Baling with the cosmological priority of the deity. As such, more than any other clan in Romanduru, the people of Buang Baling are responsible for the 'health' of the domain, including the village centre. This, I argue, is the imperative that encouraged the tana pu'an reject the proposed road. It is also the imperative that encouraged the contesting faction submit to the authority of the tana pu'an in this matter. For, although the tana pu'an is most responsible, all members of the community have a stake in the maintenance of good relations with spiritual powers. In fact, some 20 years ago the wu'a mahé of one Romanduru clan was repaired using cement and, I was told, shortly afterwards seven different members of this clan, including the clan head, were injured or killed in unusual circumstances. In other words, all the inhabitants of Romanduru, including the pro-road faction, were aware of dangerous occult consequences for disrupting the sacred village centre. The key question now becomes, 'why was a road through the centre of Romanduru village proposed when its rejection was ultimately never in doubt?'

In purely practical terms, the construction of the road would undoubtedly make life easier for many people, including the tana pu'an. For those living near the top of the village, close to the sole access road, a new road would facilitate the transportation of crops harvested in gardens located on the ridgeline and valley slopes below the village. At the moment all harvested cocoa, cloves and coconuts are carried by foot and shoulder in bags weighing up to 50 kilograms. Depending on the garden's position, such loads are carried for a number of kilometres, and several harvesting hours are lost per day as a result. It goes without saying that a road allowing motorcycle, or even truck, access to these gardens would greatly increase harvesting efficiency. For those living at the bottom end of the village, closer to the gardens but further from the top access road, a new road would also ease crop transportation, especially as the yields must be delivered personally to the agents in the coastal town of Geliting. Moreover, distance from the top access road means that building materials must be hand carried, at an extra cost, to construction sites for new houses or extensions, and parking and storage of motorcycles must be negotiated with those living close to the access road. It is also notable that electricity cables do not extend to the lower section of the village and, in general, these residents 
state that the further one is from a road, the further one is from the benefits of modernity.

There are, however, alternative routes that could have been lobbied for. A road could circumnavigate the village centre by being routed behind either row of the parallelly aligned houses. Or, a road could be constructed from an access point on the neighbouring ridge-line and be routed through the valley and connect to the lower houses of Romanduru from the northern side. Each of these alternatives were spoken of by various members of the community and each was readily dismissed because of the need to occupy private land, and thus reduce the arable land of some farmers. Furthermore, these roads would be difficult and expensive to build because of their position along the steeply sloping valley walls. In fact, the economic and logistical challenges of these alternative routes are not insurmountable, and in the most recent news I have received (some two years after the heat of the dispute described here) a road connecting the lower section of Romanduru to the neighbouring ridge-line is under development.

The dispute is characterized by a situation in which a road that would benefit all the village was proposed by some parties to be built through the village centre, even though this location would engender spiritual sanction and other routes are available. The tana pu'an was bound to reject this proposal, and had the authority to do so, and yet the proposal was still made. There were no hard boundaries between pro-road and anti-road factions that strictly divided all the village's clans, however it was clear that the tana pu'an clan, Buang Baling, were as a whole adamantly against the road. Those contesting the tana pu'an were led by members of several other clans, including members of the two clans who settled in Romanduru immediately after Buang Baling, namely Mana and Klukut Mude La'u. Although I did not poll the entire village on what was at the time a very sensitive matter, the general relationship between opinion and clan membership plainly corresponded to the 'source' and 'product' structure of precedence that differentiates the tana pu'an clan from all the others.

With this structure of precedence in mind, I wish to argue that the road proposal was made by prominent members of the non-tana pu'an clans, not to secure the road, but to contest the authority of the clan Buang Baling as 'source of the domain'. Paradoxically, this contestation helped to re-legitimate Buang Baling's authority. This last point will become clear as we consider the background of the road dispute and the strategies of contestation used.

The clans contesting the authority of the tana pu'an did so at a time when clan Buang Baling was in transition. The head of the clan, and thus the personification of the tana pu'an, had been ill for several years and died in early 2006. As is normally, though not necessarily, the case, the position of clan headship passed to the deceased's eldest son. This was not an easy transition. 
For decades the eldest son had lived away from Romanduru as a transmigration worker. Having lived so long away from home the new tana pu'an was not as knowledgeable about local history and cosmology as his father had been. The situation was further complicated by the succession of the former tana pu'an, which some in the village considered questionable. While this succession had occurred many years ago, the personal strength of character of the tana pu'an had nullified the matter, and people only dared to raise this matter after his death. And so at the time of the road dispute the tana pu'an clan of Romanduru was weakened by internal difficulties relating to the transition between clan leaders occasioned by death. Although the authority of the source of the domain is always upheld in the poetics of clan histories, at such a time the clan's ability to enact its authority is at its most fragile. In other words, the time was ripe for contestation by other clans and, equally, the integrity of the system as a whole required re-affirmation.

The strategies of contestation employed by the pro-road faction extended beyond a simple contentious proposal. Numerous power-plays were set in motion. I do not doubt that many plays were too subtle for my understanding, and so here I will only relate to the two most public challenges to the authority of the tana pu'an. First, an attempt was made to pressure the new tana pu'an into conducting incorrect ritual action. The tana pu'an was asked by a member of another clan to seek advice from the deity and ancestor spirits regarding the propriety of the road, and potentially sanctify the project, by making a tung piong sacrificial offering at clan Buang Baling's wu'a mahé ritual altar. There are several types of ritual altar in Krowé, and the wu'a mahé has very restricted use in that it is only used to offer sacrifices during the lodo hu'er mortuary rites. To have performed a sacrifice in this context would have been devastating for the reputation of the new tana pu'an. Second, a provocative tung piong sacrifice was performed at the lower edge of the village on a temporary ritual altar (watu mahang tung piong). This ritual was performed correctly and was legitimately performed to sanctify the widening of the footpath that connects the lowest houses to the village centre. Although this was a seemingly innocuous event, the footpath would eventually connect to any road routed through the village centre, and the positioning of the temporary ritual altar was precariously close to the village centre. In its suggestive timing and positioning this ritual was construed by many as an attempt to pre-emptively sanctify the village centre in preparation for roadwork without the express permission of the tana pu'an.

The important point to be made here is that both 'contestations' were unlikely to be successful. Although the events took place in a tense and exciting atmosphere and were conducted with haste, confusion, emotion and a degree of intoxication, I suspect that all sides were cognizant of the fallibility of these tactics of contestation. Despite his time away from the village, the new tana pu'an was more than capable of recognizing the proper use of ritual altars. And 
the ritual sanctification of the widened footpath was correct enough to justify its ostensible purpose, and its covert intention to sanctify a simple footpath was ambiguous enough to be ignored. The tana pu'an was challenged, but he and his clan were only challenged in a way to which they could be expected to ably respond. By responding to these contestations with such authority, the condition of uncertainty that initially prompted the contestation was effectively trumped.The strategic use of ritual to attempt to sanctify road construction and circumvent the authority of the tana pu'an, while perhaps sincere in its implementation, was not in fact a powerful challenge to the order of precedence. It is possible that heavier pressure could have been exerted on the tana pu'an to substantially weaken his authority within the existing order of precedence, however in my view this degree of contestation was not attempted.

In sum, at the time of the proposed roadworks the authority of the tana pu'an was fragile due to problems of succession. The efforts to contest the authority of the tana pu'an provided a platform on which the tana pu'an was then able to re-assert his and his clan's authority. In other words, only after staving off several challenges to his wavering authority was the recently inducted tana $p u^{\prime}$ an of Romanduru able to preside with great authority over the domain's sacred sites. Several questions arise from this conclusion. Were the individuals contesting the tana $p u$ 'an wittingly re-legitimating the tana $p u^{\prime} a n^{\prime}$ s weakened authority with the objective of supporting Romanduru's traditional order of precedence? Or, alternatively, were they sincere in their efforts to undermine the tana pu'an and unwittingly subject to a structural, homeostatic regulator that automatically restored balance? Further, given that a truly successful contestation of a particular Krowé order of precedence would effectively undermine the cosmological tenants on which the system itself is based, we must ask what benefits can be gained by any contestation at all?

\section{Conclusion}

Finding answers to the questions raised above is beyond the scope of the current investigation. Nevertheless such questions are useful for delineating the way forward for studies of precedence in Krowé, and their answers are essential for attaining a more complete understanding of Krowé social life. With this paper I have provided a platform on which to achieve these aims by describing the structure of Krowé precedence and its particular manifestation in the Romanduru domain. I then proceeded to outline a recent event in which the Romanduru structure of precedence was articulated and contested by the 'source' clan, Buang Baling, and a pro-road faction led by members of a number of 'product', or subsequent, clans. With this discussion I have shown that precedence, when used as an analytical concept, is as much a theory of social action as it is a theory of structural status differentiation. Precedence refers to a structure of relations between the clans of a domain based on the sequenced arrival of proto-ancestors 
chanted in ritual language and which assigns different responsibilities to the different clans. Precedence also refers to embodied co-operative and contested relationships between clans as they contract marriages, offer and receive tributes, and generally conduct village affairs - as was the case when different clan members challenged each other over the road project. And yet, having come this far, when we seek to understand the outcomes of a contested order of precedence, we arrive back at another problem defined by seemingly dichotomous notions of structure and agency.

I have demonstrated that the authority of Romanduru's tana pu'an was rejuvenated by the challenge of the pro-road faction. However, we do not yet know if the pro-road faction intentionally withheld from launching a sustained attack on the tana pu'an, or if their actions were limited by structural determinants. The definition of precedence as both structural and agential is a lesson that can be carried forth into future analyses of the outcomes of contestation, whether they be focused on Krowé, Sikka, or beyond. Vischer (1996) and Fox (1989) have shown that the possibility of contestation is inherent in all structures of precedence, whether that be in ritual performances or in the recursion and reversal of dyadic sets in ritual language. Additionally, I have emphasized in this paper that a practical instance of contestation in Romanduru was at the heart of an event that outwardly reflected a tension between tradition and modernity. Thus, precedence is made legitimate and relevant to a community by their actions as they seek to contest (or preserve in response to contestation) an order of precedence, and such actions can be fundamental to the motivations and behaviour of people in many different spheres of social life. We must now turn our attention to producing more detailed ethnography that reaches into the relationship between structure and agency as it is expressed in the processes and outcomes of contestation. This will not only deepen our understanding of precedence, of which contestation is an integral part, but also broaden our understanding of societies in which the full influence of precedence in contemporary social life has yet to be charted.

\section{References}

Arndt, P.

[1993]2002 Gesellschaftliche Verhältnisse im Sikagebiet (ostl. Mittelflores). Ende, Flores: Arnoldus.

Butterworth, D.J.

2008 Lessons of the ancestors: ritual, education and the ecology of mind in an Indonesian community. Unpublished PhD thesis. Melbourne: Department of Anthropology, The University of Melbourne. 
Cunningham, C.E.

1964 Order in the Atoni house. Bijdragen tot de Taal-, Land-en Volkenkunde 120:34-68.

Forth, G.

1998 Beneath the volcano: religion, cosmology and spirit classification among the Nage of eastern Indonesia. Koninklijk Instituut voor Taal-, Land- en Volkenkunde, Verhandelingen 177. Leiden: KITLV Press.

Fox, James J.

1989 Category and complement: binary ideologies and the organization of dualism in eastern Indonesia. In David Maybury-Lewis and Uri Almagor (eds), The attraction of opposites: thought and society in the dualistic mode, pp. 33-56. Ann Arbor: The University of Michigan Press.

1996 The transformation of progenitor lines of origin: patterns of precedence in eastern Indonesia. In James J. Fox and Clifford Sather (eds), Origins, ancestry and alliance: explorations in Austronesian ethnography, pp.130-153. Canberra: Department of Anthropology, Research School of Pacific and Asian Studies, The Australian National University. Comparative Austronesian Series, ANU E Press: http://epress.anu.edu.au/.

1997 Genealogy and topogeny: towards an ethnography of Rotinese ritual place names. In James J. Fox (ed.), The poetic power of place: comparative perspectives on Austronesian ideas of locality, pp.91-102. Canberra: Department of Anthropology, Research School of Pacific and Asian Studies, The Australian National University. Comparative Austronesian Series, ANU E Press: http://epress.anu.edu.au/.

Fox, James J. (ed.)

1993 Inside Austronesian houses: perspectives on domestic designs for living. Canberra: Department of Anthropology, Research School of Pacific and Asian Studies, The Australian National University. Comparative Austronesian Series, ANU E Press: http://epress.anu.edu.au/.

Lewis, E.D.

1988 People of the source: the social and ceremonial order of the Tana Wai Brama on Flores. Verhandelingen van het Koninklijk Instituut voor Taal-, Landen Volkenkunde 135. Dordrecht, Holland/Providence, USA: Foris Publications.

1996a Origin structures and precedence in the social orders of Tana 'Ai and Sikka. In James J. Fox and Clifford Sather (eds), Origins, ancestry and alliance: explorations in Austronesian ethnography, pp.154-174. Canberra: 
Department of Anthropology, Research School of Pacific and Asian Studies, The Australian National University. Comparative Austronesian Series, ANU E Press: http://epress.anu.edu.au/.

1996b Invocation, sacrifice, and precedence in the Gren Mahé rites of Tana Wai Brama, Flores. In S. Howell (ed.), For the sake of our future: sacrificing in eastern Indonesia, pp.112-131. Leiden: CNSW Publications Vol. 42.

McKinnon, Susan

1991 From a shattered sun: hierarchy, gender, and alliance in the Tanimbar Islands. Madison: The University of Wisconsin Press.

McWilliam, A.R.

1997 Mapping with metaphor: cultural topographies in west Timor. In James J. Fox (ed.), The poetic power of place: comparative perspectives on Austronesian ideas of locality, pp.103-115. Canberra: Department of Anthropology, Research School of Pacific and Asian Studies, The Australian National University. Comparative Austronesian Series, ANU E Press: http://epress.anu.edu.au/.

Metzner, J.K.

1982 Agriculture and population pressure in Sikka, Isle of Flores. a contribution to the study of the stability of agricultural systems in the wet and dry tropics. Development Studies Centre Monograph No. 28. Canberra, Australia, and Miami, Florida, USA: The Australian National University.

Traube, E.G.

1986 Cosmology and social life: ritual exchange among the Mambai of East Timor. Chicago: The University of Chicago Press.

Vischer, M.P.

1996 Precedence among the domains of the Three Hearth Stones: contestation of an order of precedence in the Ko'a ceremonial cycle (Palu'é Island, eastern Indonesia). In James J. Fox and Clifford Sather (eds), Origins, ancestry and alliance: explorations in Austronesian ethnography, pp.175-198. Canberra: Department of Anthropology, Research School of Pacific and Asian Studies, The Australian National University. Comparative Austronesian Series, ANU E Press: http://epress.anu.edu.au/.

Wurm, S and S. Hattori

1983 Language atlas of the Pacific area. Part 2. Canberra: Australian Academy of the Humanities. 


\section{ENDNOTES}

1 The ethnographic material used in this paper was collected during fieldwork in Sikka Regency in 2005 and 2006. I would like to thank Candraditya Research Centre for the Study of Religion and Culture for their sponsorship of my research. I would also like to thank Prof. James Fox, Dr E. Douglas Lewis and Dr Peter Dwyer for their comments and assistance.

2 I have argued elsewhere (Butterworth 2008) that the ethnonym 'Krowé' is an imperfect generalization of the variety of distinctive villages and clans that are found in the central highlands of Sikka Regency. For the purposes of stylistic clarity I will use Krowé in this paper. I ask the reader to be mindful that the term is not widely used locally, and in daily life people most commonly identify with their villages and clans.

${ }^{3}$ I am hesitant to use the prefix 'pre' (that is, pre-rajadom and pre-Catholic) or the term 'indigenous' in this context because the rajadom is largely of indigenous production and many elements of the Ata Sikka indigenous cosmology are still practised alongside Catholicism (for example, bridewealth exchanges).

4 Tana pu'ang is cognate with tana pu'an, and is indicative of Ata Sikka, rather than Ata Krowé, usage.

5 The indigenous language spoken in Krowé villages is a dialect of Sara Sikka, a language that Wurm and Hattori (1983) classify as part of the Flores-Lembata (Lomblen) Subgroup in the Timor Area Group in the Central Malayo-Polynesian Subgroup of the non-Oceanic Austronesian languages. Most people also speak the national language Bahasa Indonesia, which is used in schools, on official occasions such as governmental meetings, and when trading or otherwise engaging with non-Sikkanese speaking people. However, the indigenous language is most frequently spoken, albeit now with a considerable mixture of Indonesian words and phrases. The local language is often revealingly called bahasa itan, which is a mixture of Indonesian and Sara Sikka meaning 'our language'.

${ }^{6}$ Kewapante, the sub-district (kecamatan) of which Romanduru is part, has one of the highest population densities for a rural area in the entire province (444.39 people $\left.\mathrm{p} / \mathrm{km}^{2}\right)$.

7 Large, recently constituted non-origin villages are called natar werun (new village). Small settlements that are located within a tana as overflow from the natar gun (origin village) are called klo'ang (hamlet). These settlements are not constituted by 'wisung wangar. However, some natar tana (such as Klo'ang Popot and Hewot Klo'ang) take the name klo'ang. It is possible that in the distant past these villages developed from klo'ang into independent tana.

8 Krowé clans are exogamous, named descent groups. Children are born into their parents clan, and when females marry they enter their husband's clan. A male can only change clans in special circumstances, such as when he cannot afford bridewealth and thus enters his wife's clan in a marriage ritual called lébo kuat (cook the rice to enter the clan).

9 Arndt ([1933]2002:101) defines the kuat wungung of Sikka and Nita based on totemism, stating that they are 'a group of people who have a special relationship with a particular species of animal or plant and because of this relationship they are unified with each other'. My data supports this definition only insofar as each clan has specific taboo plants or animals which cannot be consumed. However, nowadays such totemic taboos have little practical relevance to the majority of the community, and membership to a descent group is measured more so through descent and marriage.

10 Du'a Wio Bota are two women named Wio and Bota and Mo'an Supung Balen Sina are two men named Supung and Balen Sina whose names are combined as one, as is stylistically often the case in ngeng ngerang.

11 Ata higi mitan literally means 'people with black teeth'. The extended form is ata higi mitan here meran which means 'people with black, yellow and red teeth'. This phrase refers to the fact that humans are creatures who smoke tobacco and chew betel and areca quids. By smoking and chewing people are distinct from lesser creatures (for example, pigs are said to have white teeth), and are thus 'wise'.

12 Sugar palm (BI: enau) (L: arenga pinnata/saccharifera).

13 This rocky outcrop is located at the centre of Romanduru village.

14 Wair wulut is the name of the Romanduru drinking water spring.

15 Wuen is cognate with ue (elder).

16 This is the 'wisung wangar of clan Klukut Mudé La'u, located at the bottom of Romanduru village.

17 This is the 'wisung wangar of clan Mana, located on the northern side of the village.

18 A tadan (or tada) is a spiritual barrier erected around a village with ritual to protect it from harm. 